\title{
Clinical judgment in medication administration among nursing students
}

\author{
Leona Konieczny* \\ Department of Nursing, Central Connecticut State University, New Britain, CT, United States
}

Received: June 12, 2017

DOI: $10.5430 / \mathrm{cns} . v 5 \mathrm{n} 4 \mathrm{p} 52$
Accepted: August 12, 2017

URL: https://doi.org/10.5430/cns.v5n4p52

\begin{abstract}
Nursing education includes the area of pharmacological therapies. Nursing educators may benefit from having students think like a nurse related to medication administration. The increased use of prescription medication and the complexities of medication administration present the need for clinical judgment. Simulation is used as an educational strategy to provide the opportunity for students to practice safe interventions which require the use of judgment to notice changes and interpret and intervene correctly. The comparison of low-fidelity and high-fidelity simulation experience in a study sample $(\mathrm{n}=126)$ is examined for the effect on clinical judgment. The Lasater Clinical Judgment Rubric (LCJR) is used to score students after the simulation related to medication administration. Two of the items in the LCJR, noticing deviations $(p=.35)$ and self-analysis $(p=.32)$, are positively affected by the level of fidelity of the simulation. A diverse, nontraditional student study sample demonstrated consistency in LCJR scoring. The outcome of increased clinical judgment may improve safety and nursing care in medication administration among nursing students.
\end{abstract}

Key Words: Clinical judgment, Simulation, Medication administration, Nursing student

\section{INTRODUCTION}

\subsection{Teaching safe medication administration}

There are nursing education curricula which include pharmacology course(s) that are separate from the clinical nursing courses. It is in the courses with clinical experience that students have the ability to apply clinical judgment. A nurse administers medications and uses judgment to assess and intervene based on an individual client's response(s). The judgment that is used extends beyond the traditional rights of medication administration. The traditional rights of medication administration are patient, medication, dose, time, and route. These rights have been increased by selected schools to include the right documentation, right reason, and right effect. The increased use of prescription of medication has highlighted the importance for nursing students to not only have knowledge about medication administration but to also apply clinical judgment. The Joint Commission National Patient Safety Goals includes the use of medicines safely for hospital, long term and home care. ${ }^{[1]}$ In addition safety is an expected competency in pre-licensure nursing programs. ${ }^{[2]}$ Nursing students focus on medication administration skills. The challenge for nurse educators is to provide learning opportunities to foster clinical judgment related to medication administration. This quantitative study describes the impact of high-fidelity simulation on clinical judgment related to medication administration among senior nursing students. Fidelity in simulation refers to the degree of realism.

The curriculum at the study site included pharmacology

\footnotetext{
*Correspondence: Leona Konieczny; Email: konieczny@ccsu.edu; Address: Department of Nursing, Central Connecticut State University, 1615 Stanley St., New Britain, CT, United States.
} 
courses that were separate from the clinical courses. Students verbalized disconnect between the two courses. The researcher of this study observed that students concentrated on skill acquisition such as the use of two identifiers, preparation of medication, and documentation. Prior to this research, when students were questioned concerning the rationale for administration, the response was "because it's prescribed or there's an order". The question examined is whether the fidelity of simulation experience has an effect on clinical judgment related to medication administration. The population is nursing students in a pre-licensure program preparing students to become Registered Nurses. The intervention is a simulation experience. The comparison is low-fidelity and high-fidelity simulation. The outcomes are evaluations using the Lasater Clinical Judgment Rubric (LCJR). The time is during the fall semester of the senior year.

\subsection{Clinical judgment}

Clinical Judgment is the process in which the nurse notices and interprets data, initiates nursing interventions and evaluates response(s), and reflects on these steps. ${ }^{[3]}$ Clinical judgment means an interpretation of a patient's needs or health issues, decision to take an action, and use a standard approach or create a new approach to produce a positive patient response. Noticing, Interpreting, responding, and Reflection are the four elements of Tanner's Integrative Clinical Judgment Model. ${ }^{[3]}$ Lasater used Tanner's Model to create a rubric that explains the levels in clinical judgment, the LCJR. ${ }^{4]}$ There are eleven specific components in the LCJR which are listed in Table 1. A combined quantitative and qualitative study identified an inter-rater reliability of $90 \%$ between the two raters using the LCJR. The researchers did not know the students and graded the rubric from videos of scenario performances by nursing students. ${ }^{[5]}$ Another study calculated the reliability of the LCJR at 0.889 and found the inter-rater reliability for agreement strategy was $92 \%-96 \% .^{[6]}$ The simulation and LCJR was found to bridge theory and practice and to develop students' thinking and clinical judgment. The bridge between theory and practice is most important because this gap exists in many practicebased learning situations. The LCJR provides faculty and students with a common language to assess students' progress in clinical judgment development and goal setting. ${ }^{\text {[7] }}$ A study by Lasater attempted to compare two focus groups for student experiences, traditional and non-traditional, with highfidelity simulation and clinical judgment. Lasater described traditional as younger than 24 years, female, and White. Nontraditional students were described by Lasater as 25 years or older, male, or racial/ethnic minority. The 15 students who volunteered for the focus group in the study were all traditional students. ${ }^{[8]}$ There is a need to examine the LCJR

Published by Sciedu Press with more diversity among study participants.

\subsection{Medication administration}

Reid-Searl et al., in a study about level of supervision, of pre-licensure nursing students, found an expressed a lack of confidence in their knowledge and ability to administer medications. ${ }^{[9]}$ Sears et al. found inexperience and distractions were the major reasons for medication errors in nursing students. Their case-control study performed with undergraduate nursing students showed students' medication mistakes in clinical were less when exposed to a simulation experience involving a similar situation $(p<.05) .{ }^{[10]}$ Ndosi \& Newell ${ }^{[11]}$ conducted a non-experimental correlational study on pharmacology knowledge in nurses found the majority of nurses in the study sample, $57.2 \%$, demonstrated inadequate pharmacology knowledge. Using questionnaires that required short answer responses, their study reported three important points: nurses have insufficient knowledge of pharmacology, nurses and educators are dissatisfied with the amount of pharmacology education provided in pre-licensure nursing education programs, and although nurses are able to identify actions and indications, they are unable to identify mechanism of action and drug interactions. In medication administration, the nurse's role goes beyond following procedure. Critical thinking and judgment are parts of the vigilance used by nurses to provide safe and effective care. ${ }^{[12]}$

\subsection{Simulation}

A meta-analysis of 12 studies reported simulation as a valid teaching/learning strategy. ${ }^{[13]}$ In addition to finding simulation as valid, six of the reviewed studies demonstrated gains in knowledge, critical thinking, and confidence. ${ }^{[13]}$ A pilot study found a positive relationship between knowledge and performance based variables with the use of high-fidelity simulation. ${ }^{[14]}$ A qualitative study with nursing student participants found simulation fidelity and working with others as common themes in simulation as a teaching strategy. ${ }^{[15]}$ A descriptive report found simulation serves to reinforce the culture of safety in nursing. ${ }^{[16]}$

Simulation has been described in the literature to strengthen nursing students' performance prior to a medication administration exam. Harris et al. described significantly higher scores on the exam as simulation provided a contextual reference to apply medication calculation and administration skills. ${ }^{[17]}$ Students who had an enhanced clinical rotation with the addition of simulation demonstrated a rise in knowledge and self-reports of increased confidence. ${ }^{[18]}$ While both of these studies provide context, they focus on skill acquisition rather than application of judgment. Simulation has been effectively utilized to improve clinical judgment in rapid re- 
sponse situations where students are presented with rapidly declining simulated patient status. ${ }^{[19]}$ An international study used simulation to demonstrate expert role modeling of clinical judgment to nursing students related to the care of older adults. ${ }^{[20,21]}$ A study of 42 students using high-fidelity simulation involving a respiratory care scenario demonstrated transfer of learning to application. ${ }^{[22]}$ However, other literature finds that the transfer of learning outcomes is unaffected by the fidelity of simulation. ${ }^{[23]}$

\section{METHOD}

\subsection{Setting \& sample}

The question is the effect of a simulation experience on clinical judgment related to medication administration. The study received approval from the Institutional Review Board. Dr. Lasater gave permission for the use of the LCJR. Study participants signed an informed consent. Study participants completed a questionnaire to self-report age, gender, race, and work experience in health care.

Study participants were nursing students entering the third semester of a nursing program which provides nursing courses over four semesters. Students were enrolled in two required courses, which were a pharmacology course and medical-surgical nursing course. The medical-surgical nursing course had theory and clinical components. The program was in a public college in a capital city in the Northeastern United States. Study participants were unknown to the investigator prior to the study. Study participants were randomly assigned into two groups.

Of the 132 eligible participants in the class, 126 met the inclusion criteria for the study. Five students were excluded because they were repeating at least one of the courses and one student was absent. There were 65 participants in the low-fidelity group and 61 in the high-fidelity group. To prevent contamination all simulation experiences occurred during the same day. In both the low-fidelity and high-fidelity groups, the same three simulation scenarios were presented requiring use of clinical judgment related to medication administration. The medication administration records were the identical for students in both groups. Study participants then had clinical judgment measured using the LCJR five to six weeks later by clinical faculty.

The 18 clinical faculty, which included full-time and parttime faculty, were blinded to whether the study participants were in the low-fidelity or high-fidelity group. The clinical faculty did not participate in the simulations. Uniform instruction was provided to clinical faculty and all clinical faculty had access to resources to score using the LCJR. The rationale for the time delay was to provide all study par- ticipants to have had multiple opportunities to administer medications at the clinical site. The evaluators would be able to rate the student on overall application of judgment to avoid an uncharacteristically high performing or low performing day.

\subsection{Study implementation}

The three scenarios focused on content taught in both courses including care of clients with endocrine, cardiac, and respiratory nursing needs. The interventions that the students performed were previously learned assessment such as vital signs and blood glucose monitoring and auscultation of heart and lung sounds. Study participants had been exposed to simulation on campus and medication administration at clinical sites during the two previous semesters.

Since the study participants were performing in groups of three, they were oriented at the beginning of each scenario to verbalize assessment findings and verbalize interventions when they were performed. The same directions were given to study participants in the low-fidelity and high-fidelity groups. The low fidelity group had experience with a static mannequin with the facilitator providing responses. The high-fidelity group had experience with a human patient simulator with the capability to display vital signs on a monitor. The human patient simulator simulated heart and lung sounds and other physical effects.

The facilitator was present for low-fidelity and high-fidelity groups. Participants were expected to administer medications in response to performing an assessment, accurately interpreting the findings, and simulated patient's responses. In one scenario, participants needed to measure blood glucose prior to providing nutrition. In addition, participants were required to use to make a decision and administer baseline insulin and coverage insulin to a simulated patient with diabetes mellitus. In another scenario, participants were caring for a simulated patient with heart failure. Participants used clinical judgment, to assess vital signs, heart and lung sounds and check serum laboratory values before administering diuretics and cardiac medications. Participants could also use judgment related to initiating cardiac monitoring, recognizing alterations in heart rate or cardiac rhythm, and notifying the prescriber. The third scenario involved participants using clinical judgment to monitor pulse oximetry, auscultate lung sounds, administer oxygen, and administer oral and nebulizer medications.

The responses of the simulated patients were dependent on the use of clinical judgment by participants. For example, if the simulated patient was not given coverage insulin, the simulated patient changed with signs consistent 
with hyperglycemia. Conversely, if the simulated patient received too much insulin or the wrong type of insulin, the scenario changed to signs and symptoms consistent with hypoglycemia. Study participants needed to recognize deviations from baseline, interpret correctly, and perform appropriate nursing interventions. In the cardiac scenario, if the participants did not check serum potassium and heart rhythm before administering medications, the simulated patient developed increased irregular pulse, ventricular ectopy and eventually deteriorating status due to ventricular tachy- cardia. Likewise, the participants in the respiratory scenario needed to intervene before the simulated patient developed respiratory distress. Debriefings were conducted by the facilitator at the conclusion of the low-fidelity and high-fidelity simulations.

\section{RESUlTS}

\subsection{Clinical judgment findings}

The results of the data collection for the LCJR is in Table 1.

Table 1. LCJR results

\begin{tabular}{|c|c|c|c|c|}
\hline LCJR Components & Low Fidelity $(n=64)$ & High Fidelity $(n=61)$ & Total $(n=125)$ & Pearson Chi square \\
\hline $\begin{array}{l}\text { Noticing: Focused } \\
\text { Observation }\end{array}$ & $\begin{array}{l}\text { - } \text { Beginning } 0(0 \%) \\
\text { - } \text { Developing } 16(25 \%) \\
\text { - Accomplished } 29(45.3 \%) \\
\text { - } \text { Exemplary } 19(29.7 \%)\end{array}$ & $\begin{array}{l}\text { - } \text { Beginning } 4(6.6 \%) \\
\text { - Developing } 19(31.1 \%) \\
\text { - Accomplished } 22(36.1 \%) \\
\text { - Exemplary } 16(26.2 \%)\end{array}$ & $\begin{array}{l}\text { - } \text { Beginning } 4(3.2 \%) \\
\text { - } \text { Developing } 35(28 \%) \\
\text { - Accomplished } 51(40.8 \%) \\
\text { - Exemplary } 35(28 \%)\end{array}$ & 5.406 \\
\hline $\begin{array}{l}\text { Noticing: } \\
\text { Recognizing } \\
\text { Deviations }\end{array}$ & $\begin{array}{l}\text { - } \text { Beginning } 0(0 \%) \\
\text { - Developing } 14(21.9 \%) \\
\text { - Accomplished } 40(62.5 \%) \\
\text { - Exemplary } 10(15.6 \%)\end{array}$ & $\begin{array}{l}\text { - Beginning } 4(6.6 \%) \\
\text { - } \text { Developing } 20(30.8 \%) \\
\text { - Accomplished } 25(41 \%) \\
\text { - } \text { Exemplary } 12(19.7 \%)\end{array}$ & $\begin{array}{l}\text { - Beginning } 4(3.2 \%) \\
\text { - Developing } 34(27.2 \% \\
\text { - Accomplished } 65(52 \%) \\
\text { - Exemplary } 22(17.6 \%)\end{array}$ & 8.635 \\
\hline $\begin{array}{l}\text { Noticing: Information } \\
\text { Seeking }\end{array}$ & $\begin{array}{l}\text { - } \text { Beginning } 0(0 \%) \\
\text { - } \text { Developing } 13(20.3 \%) \\
\text { - Accomplished } 28(43.8 \%) \\
\text { - } \text { Exemplary } 23(35.9 \%)\end{array}$ & $\begin{array}{l}\text { - Beginning } 1(1.6 \%) \\
\text { - Developing } 11(18 \%) \\
\text { - Accomplished } 30(49.2 \%) \\
\text { - Exemplary } 19(31.1 \%)\end{array}$ & $\begin{array}{l}\text { - Beginning } 1(0.8 \%) \\
\text { - Developing } 24(19.2 \%) \\
\text { - Accomplished } 58(46.4 \%) \\
\text { - Exemplary } 42(33.6 \%)\end{array}$ & 1.545 \\
\hline $\begin{array}{l}\text { Interpreting: Prioritize } \\
\text { Data }\end{array}$ & $\begin{array}{l}\text { - Beginning } 2(3.1 \%) \\
\text { - Developing } 15(23.4 \%) \\
\text { - Accomplished } 32(50 \%) \\
\text { - Exemplary } 15(23.4 \%)\end{array}$ & $\begin{array}{l}\text { - Beginning } 4(6.6 \%) \\
\text { - Developing } 18(29.5 \%) \\
\text { - Accomplished } 25(41 \%) \\
\text { - Exemplary } 14(23 \%)\end{array}$ & $\begin{array}{l}\text { - Beginning } 6(4.8 \%) \\
\text { - Developing } 33(26.4 \%) \\
\text { - Accomplished } 57(45.6 \%) \\
\text { - Exemplary } 29(23.2 \%)\end{array}$ & 1.763 \\
\hline $\begin{array}{l}\text { Interpreting: Making } \\
\text { Sense of Data }\end{array}$ & $\begin{array}{l}\text { - } \text { Beginning } 1(1.6 \%) \\
\text { - } \text { Developing } 14(21.9 \%) \\
\text { - Accomplished } 38(59.4 \%) \\
\text { - } \text { Exemplary } 11(17.2 \%)\end{array}$ & $\begin{array}{l}\text { - Beginning } 4(6.6 \%) \\
\text { - Developing } 12(19.7 \%) \\
\text { - Accomplished } 31(50.8 \%) \\
\text { - Exemplary } 14(23 \%)\end{array}$ & $\begin{array}{l}\text { - Beginning } 5(4 \%) \\
\text { - Developing } 26(20.8 \%) \\
\text { - Accomplished } 69(55.2 \%) \\
\text { - Exemplary } 25(20 \%)\end{array}$ & 2.954 \\
\hline $\begin{array}{l}\text { Responding: Calm, } \\
\text { Confident Manner }\end{array}$ & $\begin{array}{l}\text { - } \text { Beginning } 1(1.6 \%) \\
\text { - } \text { Developing } 14(21.9 \%) \\
\text { - Accomplished } 30(46.9 \%) \\
\text { - } \text { Exemplary } 19(29.7 \%)\end{array}$ & $\begin{array}{l}\text { - Beginning } 1(1.6 \%) \\
\text { - Developing } 10(16.4 \%) \\
\text { - Accomplished } 36(59 \%) \\
\text { - Exemplary } 14(23 \%)\end{array}$ & $\begin{array}{l}\text { - Beginning } 2(1.6 \%) \\
\text { - Developing } 24(19.2 \%) \\
\text { - Accomplished } 66(52.8 \%) \\
\text { - Exemplary } 33(26.4 \%)\end{array}$ & 1.899 \\
\hline $\begin{array}{l}\text { Responding: Clear } \\
\text { Communication }\end{array}$ & $\begin{array}{l}\text { - } \text { Beginning } 0(0 \%) \\
\text { - Developing } 10(15.6 \%) \\
\text { - Accomplished } 32(50 \%) \\
\text { - Exemplary } 22(34.4 \%)\end{array}$ & $\begin{array}{l}\text { - Beginning } 1(1.6 \%) \\
\text { - Developing } 4(6.6 \%) \\
\text { - Accomplished } 36(59 \%) \\
\text { - Exemplary } 20(32.8 \%)\end{array}$ & $\begin{array}{l}\text { - Beginning } 1(0.8 \%) \\
\text { - Developing } 14(11.2 \%) \\
\text { - Accomplished } 68(54.4 \%) \\
\text { - Exemplary } 42(33.6 \%)\end{array}$ & 3.832 \\
\hline $\begin{array}{l}\text { Responding: Being } \\
\text { Skillful }\end{array}$ & $\begin{array}{l}\text { - } \text { Beginning } 0(0 \%) \\
\text { - Developing } 16(25 \%) \\
\text { - Accomplished } 35(54.7 \%) \\
\text { - Exemplary } 13(20.3 \%)\end{array}$ & $\begin{array}{l}\text { - Beginning } 1(1.6 \%) \\
\text { - Developing } 12(19.7 \%) \\
\text { - Accomplished } 30(49.2 \%) \\
\text { - Exemplary } 18(29.5 \%)\end{array}$ & $\begin{array}{l}\text { - } \text { Beginning }(0.8 \%) \\
\text { - Developing } 28(22.4 \%) \\
\text { - Accomplished } 65(52 \%) \\
\text { - Exemplary } 31(24.8 \%)\end{array}$ & 2.692 \\
\hline $\begin{array}{l}\text { Reflection: } \\
\text { Self-analysis }\end{array}$ & $\begin{array}{l}\text { - Beginning } 2(3.1 \%) \\
\text { - Developing } 11(17.2 \%) \\
\text { - Accomplished } 40(62.5 \%) \\
\text { - Exemplary } 11(17.2 \%)\end{array}$ & $\begin{array}{l}\text { - Beginning } 0(0 \%) \\
\text { - Developing } 17(27.9 \%) \\
\text { - Accomplished } 25(41 \%) \\
\text { - Exemplary } 19(31.1 \%)\end{array}$ & $\begin{array}{l}\text { - Beginning } 2(1.6 \%) \\
\text { - Developing } 28(22.4 \%) \\
\text { - Accomplished } 65(52 \%) \\
\text { - Exemplary } 30(24 \%)\end{array}$ & 8.814 \\
\hline $\begin{array}{l}\text { Reflection: } \\
\text { Commitment to } \\
\text { Improvement }\end{array}$ & $\begin{array}{l}\text { - Beginning } 0(0 \%) \\
\text { - Developing } 7(10.9 \%) \\
\text { - Accomplished } 41(64.1 \%) \\
\text { - } \text { Exemplary } 16(25 \%)\end{array}$ & $\begin{array}{l}\text { - Beginning } 0(0 \%) \\
\text { - Developing } 13(21.3 \%) \\
\text { - Accomplished } 27(44.3 \%) \\
\text { - } \text { Exemplary } 21(34.4 \%)\end{array}$ & $\begin{array}{l}\text { - Beginning } 0(0 \%) \\
\text { - Developing } 20(16 \%) \\
\text { - Accomplished } 68(54.4 \%) \\
\text { - Exemplary } 37(29.6 \%)\end{array}$ & 5.289 \\
\hline
\end{tabular}


Table 2. LCJR and significance (2-sided)

\begin{tabular}{ll}
\hline LCJR & Significance \\
\hline Noticing: Focused Observation & .144 \\
Noticing: Recognizing Deviations &. $\mathbf{0 3 5}$ \\
Noticing: Information Seeking & .672 \\
Interpreting: Prioritize Data & .623 \\
Interpreting: Making Sense of Data & .399 \\
Responding: Calm, Confident Manner & .594 \\
Responding: Clear Communication & .280 \\
Responding: Intervention Flexibility & .242 \\
Responding: Being Skillful & .442 \\
Reflection: Self-analysis & $\mathbf{. 0 3 2}$ \\
Reflection: Commitment to Improvement & .071 \\
\hline
\end{tabular}

ANOVA and Pearson Chi-Square analysis was performed for the 11 items in the LCJR to examine the difference between the low-fidelity and high-fidelity simulation. Significant differences were found in two of the categories which are recognizing deviations and self-analysis $(p<.05)$. Recognizing deviations which is in the noticing section had a $p=.035$. Self-analysis which is in the reflection section had a $p=.032$. The LCJR items with the significance levels are listed in Table 2. The use of high-fidelity simulation affected two of the categories. Further analysis was done to determine if there was a difference in the LCJR related to whether a fulltime faculty member or clinical adjunct instructor performed the evaluation. When Linear-by-Linear Association analysis was done there was no significant difference between the full-time faculty or part-time clinical instructors.

\subsection{Study sample demographic results}

Study participants were diverse in age, gender, race, and work experience in health care. Eighty percent of study participants were over the age of 24 years. Thirteen per cent were male with the remaining $87 \%$ as female. The data sheet did include the option of male, female, and other but none of the study participants identified as other. Fifteen per cent of study participants self-identified race-ethnic as African-American, $11.1 \%$ as Hispanic, 5.5\% as Asian or Pacific Islander, and $1.5 \%$ self-identified as Other. A total of $33.1 \%$ of study participants were from diverse race. For work experience, $43 \%$ were not employed in health care as compared to $57 \%$ who were employed in health care. Chi square analysis demonstrated no significant differences in the demographic variables between the low-fidelity and highfidelity groups. This data is found in Table 3. ANOVA and Linear-by-Linear Association showed no differences in LCJR scores and demographic variables.

Table 3. Demographic information of participants frequency (percent)

\begin{tabular}{llll}
\hline Characteristic & Low-fidelity $(\boldsymbol{n}=\mathbf{6 5})$ & High-fidelity $(\boldsymbol{n}=\mathbf{6 1})$ & Chi square $\boldsymbol{p}$-value \\
\hline Age & $16(24.6 \%)$ & $9(14.8 \%)$ & .241 \\
- $\leq 24$ & $27(41.5 \%)$ & $31(50.8 \%)$ & \\
- $25-34$ & $11(16.9 \%)$ & $6(9.8 \%)$ & \\
- $35-40$ & $11(16.9 \%)$ & $15(24.6 \%)$ & .502 \\
- $>40$ & & & \\
Gender & $58(89.2 \%)$ & $52(85.2 \%)$ & .922 \\
- Female & $7(10.8 \%)$ & $9(14.8 \%)$ & \\
- Male & $0(0 \%)$ & $0(0 \%)$ & \\
- Other & & $39(63.9 \%)$ & \\
Race & $45(69.2 \%)$ & $11(18.0 \%)$ & \\
- White & $8(12.3 \%)$ & $7(11.5 \%)$ & \\
- African-American & $7(10.8 \%)$ & $3(4.9 \%)$ & .758 \\
- Hispanic & $4(6.2 \%)$ & $1(1.6 \%)$ & \\
- Asian & $1(1.5 \%)$ & $27(44.3 \%)$ & \\
- Other & & $34(55.7 \%)$ & \\
Work Status & $27(41.5 \%)$ & $38(58.5 \%)$ &
\end{tabular}

\section{Discussion}

Since only 2 of the 11 categories showed a significant effect from the level of fidelity of the simulation, there is minimal effect from this simulation experience on clinical judgment.
In examining this, a case can be made that the one simulation experience was not a strong enough intervention to produce an effect. Study participants exposed to high-fidelity simulation performed better in recognizing deviations from baseline. 
Self-analysis was also positively impacted by high-fidelity simulation. Nursing faculty may assign self-reflection documentation after simulation experiences as a teaching strategy. Another consideration, is that the clinical judgment was not measured before the simulation experience. In order to do this, LCJR scores would have had to be obtained in the first week or two of the fall semester. There was a potential for these scores to be low since the students would not have had clinical experience for almost three full months during summer break. Also, clinical faculty would not have the opportunity to evaluate all the students administering medications more than once if evaluated that early in the semester. In redesigning the study, a second simulation experience would be added halfway through the semester with the use of LCJR repeated at the end of the semester. The faculty provided positive unsolicited feedback about the LCJR. Nursing faculty felt this instrument more clearly measured performance as a nurse as compared to the clinical evaluation tool that was being used.

More than half of the study participants were employed in health care outside of the clinical experiences in the nursing program. It may be assumed that those employed may have more clinical judgment. However, there was no relationship between health care employment and the fidelity of simulation with clinical judgment. This may be because within job responsibilities of positions such as certified nursing assistant or technician or residential care aide, there are few opportunities to exercise judgment related to medication administration. The study sample demonstrated more diversity in age and race. Findings from diverse, nontraditional persons strengthen the body of evidence in studies of nursing students.

A study strength was that the LCJR was used as intended.
The instrument is not intended to evaluate a single occurrence but rather to provide a common language for faculty and student to discuss clinical judgment as a nurse. Another strength was the size of the sample. The non-traditional study participants was another strength. As compared to national data, this study had participants that were older and had significantly more racial diversity.

A limitation is that the demographic data were self-reported. In the future, in the demographic data for gender instead of other, the category gender neutral will be included. Another limitation is the inability to generalize to other curricula that do not include separate pharmacology courses apart from nursing courses that provide the opportunity to use clinical judgment at clinical experiences. There was not a control group without the simulation experience.

\section{Conclusions}

The use of high-fidelity simulation is useful in teaching the not only the skills of medication administration but also the application of clinical judgment. The development of clinical judgment as a nurse starts during pre-licensure education. Simulation is an educational strategy for educators to reinforce thinking like a nurse with students. Demographic characteristics did not change the scoring on the LCJR. This instrument continues to be a reliable instrument for examining clinical judgment. Data from a diverse sample adds to the evidence on characteristics of nursing students. Simulation may be used for teaching nursing students clinical judgment which will translate into the ultimate goal of improved safety and care.

\section{Conflicts of InTEREST Disclosure}

\section{REFERENCES}

[1] National Patient Safety Goals [Internet].The Joint Commission. 2017 [cited 2017 June 1]. Available from: http: //www . jointcommiss ion.org

[2] QSEN Competencies [Internet]. QSEN Institute; 2014 [cited 2017 June 1]. Available from: http://www.qsen.org/competencie s/

[3] Tanner CA. Thinking like a nurse: A research based model of clinical judgment in nursing. J Nurs Educ. 2006; 45(6): 204-211. PMid: 16780008

[4] Lasater K. Clinical judgment development: Using simulation to create an assessment rubric. J Nurs Educ. 2007a; 46(11): 496-503. PMid: 18019107

[5] Lasater K, Nielsen A. The influence of concept-based learning activities on students' clinical judgment development. J Nurs Educ. 2009;
48(8): 441-446. PMid: 19681533. https://doi.org/10.3928/ 01484834-20090518-04

[6] Adamson KA, Gubrud P, Sideras S, et al. Assessing the reliability, validity, and use of the Lasater Clinical Judgment Rubric: Three approaches. J Nurs Educ. 2012; 51(2): 66-73. PMid: 22132718. https://doi.org/10.3928/01484834-20111130-03

[7] Cato ML, Lasater K, Peeples AI. Nursing students' self-assessment of their simulation experiences. Nurs Educ Perspect. 2009; 30(2): 105-108. PMid: 19476075.

[8] Lasater K. High-fidelity simulation and the development of clinical judgment: Students' experiences. J Nurs Educ. 2007b; 46(6): 269-275. PMid: 17580739.

[9] Reid-Searl K, Moxham L, Walker S, et al. Nursing students administering medications: Appreciating and seeking appropriate supervision. J Adv Nurs. 2010; 66(3): 532-541. PMid: 20423388. 
https://doi.org/10.1111/j.1365-2648.2009.05214.x

[10] Sears K, Goldsworthy S, Goodman WM. The relationship between simulation in nursing education and medication safety. J Nurs Educ. 2010; 49(1): 52-55. PMid: 19810664. https ://doi .org/10. 392 8/01484834-20090918-12

[11] Ndosi ME, Newell R. Nurses' knowledge of pharmacology behind drugs they commonly administer. J Clin Nurs. 2008; 18: 570580. PMid: 18680489. https://doi.org/10.1111/j.1365-2 702.2008.02290.x

[12] Eisenhauer LA, Hurley AC, Dolan N. Nurses' reported thinking during medication administration. J Nurs Scholarsh. 2007; 39(1): 82-87. PMid: 17393971. https ://doi.org/10.1111/j.1547-5 $069.2007 .00148 . \mathrm{x}$

[13] Cant RP, Cooper SJ. Simulation-based learning in nurse education: Systematic review. J Adv Nurs. 2010; 66(1): 3-15. PMid: 20423432. https://doi.org/10.1111/j.1365-2648.2009.05240.x

[14] Hauber RP, Cormier E, Whyte J. An exploration of the relationship between knowledge and performance related variables in highfidelity simulation. Nurs Educ Perspect. 2010; 31(4): 242-226. PMid: 20882866.

[15] Najjar RH, Lyman B, Miehl N. Nursing Students' Experiences with High-Fidelity Simulation. Inter J Nurs Educ Scholarsh. 2015; 12(1): 1-9. PMid: 25803087. https://doi.org/10.1515/ijnes-201 5-0010

[16] MacIntyre RC, Murray TA, Teel CS, et al. Five recommendations for prelicensure clinical nursing education. J Nurs Educ. 2009; 48 : 447-453. PMid: 19681534. https ://doi.org/10.3928/014848 34-20090717-03
[17] Harris MA, Pitiglio L, Newton SE, et al. Using Simulation to Improve the Medication Administration Skills of Undergraduate Nursing Students. Nurs Educ Perspect. 2014; 35(1): 26-29. PMid: 24716338. https://doi.org/10.5480/11-552.1

[18] Pauly-O'Neill S, Prion S. Using Integrated Simulation in a Nursing Program to Improve Medication Administration Skills in the Pediatric Population. Nurs Educ Perspect. 2013; 34(3): 148-153. PMid: 23914455. https://doi .org/10.5480/1536-5026-34.3.148

[19] Lindsey PL, Jenkins S. Nursing Students' Clinical Judgment Regarding Rapid Response: The Influence of a Clinical Simulation Education Intervention. Nurs Forum. 2013; 48(1): 61-70. PMid: 23379397. https://doi.org/10.1111/nuf .12002

[20] Johnson EA, Lasater K, Hodson-Carlton K, et al. Geriatrics in Simulation: Role Modeling and Clinical Judgment Effect, Nurs Educ Perspect. 2012; 33(3): 176-180. PMid: 22860481. https : //doi.org/10.5480/1536-5026-33.3.176

[21] Dillard N, Sideras S, Ryan M, et al. A collaborative project to apply and evaluate the clinical judgment model through simulation. Nurs Educ Perspect. 2009; 30(2): 99-104. PMid: 19476074.

[22] Kirkman TR. High Fidelity Simulation Effectiveness in Nursing Students' Transfer of Learning. Inter J Nurs Educ Scholarsh. 2013; 10(1): 1-6. PMid: 23934438. https://doi.org/10.1515/ijnes-201 2-0009

[23] Norman G, Dore K, Grierson L. The minimal relationship between simulation fidelity and transfer of learning. Med Educ. 2012; 46(7): 636-647. PMid: 22616789. https : //doi .org/10.1111/j.1365 $-2923.2012 .04243 . x$ 